\title{
Bankruptcy Prediction Model: The Case of the United States
}

\author{
Xavier Brédart ${ }^{1}$ \\ ${ }^{1}$ Warocqué School of Business and Economics, University of Mons, Mons, Belgium \\ Correspondence: Xavier Brédart, Warocqué School of Business and Economics, University of Mons, Place \\ Warocqué, 17, 7000, Mons, Belgium. Tel: 32-0-6537-3213. E-mail: xavier.bredart@umons.ac.be
}

Received: December 20, 2013

Accepted: December 24, 2013 Online Published: February 25, 2014

doi:10.5539/ijef.v6n3p1

URL: http://dx.doi.org/10.5539/ijef.v6n3p1

\begin{abstract}
United States has faced a growing number of corporate bankruptcies since the subprimes crisis. This paper aims to develop an econometric forecasting model constructed from three simple and easily available financial ratios. We used a matched-pair sample of US quoted firms with half of the sample filing for chapter 11 (reorganization procedure) of the United States Bankruptcy Code for the period 2000-2012 and conducted logit regression analysis. We found that this model using three simple, few correlated and easily available financial ratios as explanatory variables shows a prediction accuracy of more than 80 percent. Besides the academic contribution to the research relative to the bankruptcy prediction, the empirical results of this study may be useful for practitioners, particularly for financial institutions interested in the probability of default of their partners.
\end{abstract}

Keywords: bankruptcy, logit, prediction model

\section{Introduction}

In today's business, resorting to a bankruptcy protection law is a common occurrence among U.S. corporations of all sizes and in all sectors (Altman, 1999). Due to the impact of this decision for many actors (e.g., financial institutions and shareholders), a major issue in the academic literature is financial distress detection. As per Article I, Section 8, of the United States Constitution, Congress has the authority to pass laws on the subject of bankruptcies. As a consequence, the "Bankruptcy Code" (Note 1), came into being in 1978 and has been amended several times since then. The main objective of this code is to "give to the honest but unfortunate debtor... a new opportunity in life and a clear field for future effort, unhampered by the pressure and discouragement of preexisting debt". The code describes six basic types of bankruptcy cases that hold the names of the chapters that describe them (chapters $7,9,11,12,13$ and 15). We focus on the occurrence of a filing for chapter 11 to reflect financial distress. Chapter 11 is an entitled reorganization whose objective is to save the business through designing a plan that must be accepted by the court. Bankruptcy prediction developed during the sixties. Although various techniques are used, studies are generally based on determining one or several variable(s) that correctly classify a paired sample of firms. According to Refait (2004), the accounting measures that have the highest discriminating power in bankruptcy analysis are related to the profitability, the liquidity and the solvency of firms.

The aim of this paper is to build a "user friendly" bankruptcy prediction model. Our study may be of interest to investors and financial institutions acting on the US standard markets. To this end, we decided to conduct a logit analysis upon a paired sample of 870 companies previously quoted on the Amex, the Nasdaq and the NYSE. Four hundred thirty-five of these entities filed for chapter 11 (reorganization procedure) of the American bankruptcy code between January 2000 and December 2012; the other 435 did not resort to bankruptcy protection during this timeframe. So for each of the companies that was engaged in a reorganization procedure, there is a corresponding one in the same field of activity and of "approximately" the same size (determined by the total assets) that has not met with the same kind of financial trouble. A logit analysis of this sample will enable us to detect financial ratios that influence the failure of firms. The results of our study show that the profitability, the liquidity and the solvency of firms were excellent predictors of financial distress for the whole period 2000-2012.

The paper proceeds as follows. The second section develops working hypotheses regarding the effects of the selected ratios on financial distress. The third section concerns our sample and the methodology used. In the fourth section, we will comment descriptive statistics, provide results of the logit model, and conduct hypothesis 
testing before discussion (section 5).

\section{Bankruptcy Prediction}

Bankruptcy prediction developed during the sixties. Although various techniques are used, studies are generally based on determining one or several variable(s) that correctly classify a paired sample of firms (Refait, 2004). Beaver (1967) conducted a seminal study on bankruptcy detection. He completed a discriminant analysis on a single ratio (cash flow on total debt). A year later, Altman (1968) undertook a similar, but multidimensional study; the discrimination was determined by a score-the «Z-score»-calculated on the basis of five accounting ratios. Linear discriminant analysis is still intensively used in practice; however, it implies the respect of some strict statistical restrictions such as the normality of the distribution of the explanatory variables. As a consequence, bankruptcy prediction models using regressions on qualitative variables as logit (Ohlson, 1980; Mensah, 1984; Zavgren, 1985; Aziz, Emmanuel, \& Lawson, 1988; Bardos, 1989; Burgstahler, Jiambalvo, \& Noreen, 1989; Flagg, Giroux, \& Wiggins, 1991; Platt \& Platt, 1991; Bardos \& Zhu, 1997; Bell, Mossman, Swartz, \& Turtle, 1998; Premachandra, Bhabra, \& Sueyoshi, 2009) and probit models (Zmijewsji, 1984; Gentry, Newblod, \& Whiteford, 1985; Lennox, 1999) have been developed, depending on whether the residuals follow a logistic or normal distribution. Duration models, similar to previous ones but making it possible to consider several periods, have also been used (Shumway, 2001; Duffie, Saita, \& Wang, 2007). Statistical methods, however, depend on restrictive hypotheses. Therefore, with the advent of computer sciences, some authors have resorted to artificial intelligence algorithms such as neural networks (Odom \& Sharda, 1990; Kim \& Kang, 2010) or genetic algorithms (Varetto, 1998; Shin \& Lee, 2002) for bankruptcy prediction modeling.

According to Refait (2004), the accounting measures that have the highest discriminating power in bankruptcy analysis are related to the profitability, the liquidity and the solvency of firms. The review of bankruptcy prediction studies from Akers, Bellovary and Giacomino (2007) reports that the following ratios are used in many studies: Net income/Total assets, Current and Solvency ratios.

Profitability. According to Bilderbeek \& Pump (2005), a company whose profits decrease over time is expected to meet high probability of facing financial difficulties. Furthermore, according to Chang et al. (1999), the profitability generated by the company is one of the primary criteria for the granting of credit by financial institutions. According Keasey \& McGuinness (1990), profitability is the most critical issue of the failure of firms. We utilize the Net income/Total assets to test our hypothesis regarding the link between profitability and financial distress.

\section{H1: Low profitability has a positive impact on the probability of financial distress of US companies.}

Liquidity. Intuitively, we assume that higher levels of liquidity will have a positive influence on the survival of businesses. Indeed, companies in distress often have low liquidity and concerns to meet their commitments. In this context, banks may tighten credit conditions to prevent future risk of failure, causing more financial troubles. A liquidity ratio is an unavoidable financial indicator as it assesses the importance of the funds available to deal with various situations. This ratio is used to check if the company is able to pay its debts and to continue his activity.

According Daubie Meskens \& (2002), and Dimitras al. (1996) and Akers et al. (2007), one of the most commonly used financial ratios to characterize the current liquidity ratio. Finally, according to the known Beaver (1967), Altman (1968), of Edminster (1972), Ohlson (1980), of Zmijewski (1984) and many other models, low liquidity generates a higher risk of default. In view of these findings, we formulate our second hypothesis as follows.

H2: A low liquidity has a positive impact on the probability of financial distress of US companies.

Solvency. The ability to repay its debts and the financial burden is the creditworthiness of the company and its financial structure may play a role in the risk of bankruptcy. When it encounters financial troubles, causing debts and financial burdens, the probability of default of the company increases dramatically. Indeed, the payment of the installments may lead the company to default. Healthy companies have greater financial autonomy than their failed counterparts. In Financial economics, the variable commonly used to determine the repayment capacity of a company is the total equity / total assets ratio. Finally, according to the known Beaver (1967), Altman (1968), Edminster (1972), Ohlson (1980), Zmijewski (1984) models and many others, a low solvency generates a higher risk of default. Accordingly, our third hypothesis is formulated as follows.

H3: A high solvency ratio has a negative impact on the probability of financial distress of US companies. 


\section{Methodology}

\subsection{Sample and Data}

The sample used in this study consists of 870 firms originally quoted on the Amex, the Nasdaq and the NYSE from January 2000 to December 2012. Four hundred and thirty-five of the 870 firms of our sample filed for chapter 11 of the United States Bankruptcy Code during this timeframe. We utilised Bloomberg to collect accounting data. We then obtained a matched pair of financially healthy companies (without any filing for bankruptcy protection law during the timeframe) via the nearest neighbour method. Healthy companies are selected amongthe list of all the companies listed on the Nasdaq and the NYSE on 13/03/2013 (more than 4000 firms). We matched industry (SIC code) and firm size (total assets). The final sample includes 870 firms.

\subsection{Measures}

Dependent Variable. A dichotomous qualitative dependent variable is commonly used for bankruptcy prediction models (Ohlson, 1980; Premachandra, Bhabra, \& Sueyoshi, 2009). We utilise one dependent variable: Financial Distress. For this study. Financial distress is a binary variable taking a value of 1 if the firm filed for chapter 7 or 11 of the American Bankruptcy Code and 0 otherwise.

Independent Variables. Our key explanatory variables are Profitability, liquidity and solvency. We measure profitability as the value of the ratio Net income/Total assets on the latest accounting fiscal year before the filing for reorganisation procedure. We measure Liquidity as the value of the current ratio on the latest accounting fiscal year before the filing for reorganisation procedure. We define Solvency as the value of the ratio Total equity/Total assets on the latest accounting fiscal year before the filing for reorganisation procedure. Data on Profitability, liquidity and solvency ratios was obtained from Bloomberg database.

\subsection{Methodology}

Since our dependent variable, financial distress, is dichotomous, we use a binary logit regression model, as it is the case in many studies regarding the occurrence of bankruptcy filing (Ohlson, 1980; Mensah, 1984; Zavgren, 1985; Aziz, Emmanuel, \& Lawson, 1988; Burgstahle, Jiambalvo, \& Noreen, 1989; Flagg, Giroux, \& Wiggins, 1991; Platt \& Platt, 1991; Bell, Mossman, Swartz, \& Turtle, 1998; Premachandra, Bhabra, \& Sueyoshi, 2009). A logit model describes the relationship between a dichotomous dependent variable that can take value 1 (bankrupt business) or value 0 (healthy), and $\mathrm{k}$ other explanatory variables $\mathrm{x}_{1}, \mathrm{x}_{2} \ldots \mathrm{x}_{\mathrm{k}}$. These variables can be quantitative or qualitative. Since the dependent variable is binary (dichotomous), the latter follows the Bernoulli distribution such that $\mathrm{Pi}=\mathrm{P}(\mathrm{yi}=1)$ is the probability of bankruptcy and $1-\mathrm{Pi}$ is the probability of non-failure. The estimated model requires the endogenous variable to be a linear combination of exogenous variables:

$y i^{*}=\beta X i+\varepsilon i$ where $\varepsilon$ is the error term and $\beta$ the vector of coefficients;

$y i=1$ if $y i^{*}>0$;

$y i=0$ if $y i^{*} \leq 0$;

The probability of non-default (a posteriori) of firm $\mathrm{i}$ is given by:

$$
P(y i=0)=P\left(y i^{*} \leq 0\right)=P(\beta X i+\varepsilon i \leq 0)=P(\varepsilon i \leq-\beta X i)=F(-\beta X i)=1-F(\beta X i)=1-P i ;
$$

Similarly, the probability of failure (a posteriori) of firm i is represented by:

$$
P(y i=1)=P(y i *>0)=P(\beta X i+\varepsilon i>0)=P(\varepsilon i>-\beta X i)=1-P(\varepsilon i \leq-\beta X i)=F(\beta X i)=P i .
$$

The logit model assumes that the errors follow a logistic distribution where the distribution function is: $\mathrm{F}(\mathrm{x})=(1$ $+\mathrm{e}-\mathrm{x})-1$. Therefore, it is possible to calculate the probability of non-default of firm I as follows: $\mathrm{P}(\mathrm{yi}=0)=$ $\mathrm{F}(-\beta \mathrm{Xi})=(1+\mathrm{e} \beta \mathrm{Xi})-1=1-\mathrm{Pi}$. Similarly, the probability of the default of firm i is: $\mathrm{P}(\mathrm{yi}=1)=\mathrm{F}(\mathrm{Xi} \beta)=$ $(1+\mathrm{e}-\beta \mathrm{Xi})-1=\mathrm{Pi}$.

The $\beta$ coefficients will be estimated using the method of maximum likelihood.

The model is analysed with stata software.

\section{Results}

\subsection{Correlations and Descriptive Statistics}

Correlations between all variables included in the model are presented in Table 1. All correlations are under .30. Moreover, the results of the analysis of variance inflation factors (VIF) report that all the variables (independent and control) have VIF under the suggested value of 10 (see Table1) with the mean VIF of 1.10 and the highest value equal to 1.15 , thus we do not have any problems with multicollinearity. 
Table 1. Correlation matrix

\begin{tabular}{llllll}
\hline & VIF & 1 & 2 & 3 & 4 \\
\hline 1 & Financial distress & 1 & & & \\
2 & Profitability & 1.09 & 1 & & \\
3 & Liquidity & 1.06 & 0.06 & 1 & \\
4 & Solvency & 1.15 & 0.28 & 0.24 & 1 \\
\hline
\end{tabular}

Table 2 reports the distribution of firms per activity field for the two subsamples. We have been able to create a perfect match between perennial and non-perennial firms regarding the activity field. Let us also notice that manufacturing, services and transportation and public utilities are the fields that are the most concerned by bankruptcy filing.

Table 2. Firms per activity field

\begin{tabular}{lll}
\hline & Non-Perennial & Perennial \\
\hline Mining & 17 & 17 \\
Construction & 6 & 6 \\
Manufacturing & 150 & 150 \\
Transportation \& Public Utilities & 83 & 83 \\
Wholesale Trade & 14 & 14 \\
Retail Trade & 45 & 45 \\
Finance, Insurance, Real estate & 34 & 34 \\
Services & 86 & 86 \\
Total & 435 & 435 \\
\hline
\end{tabular}

Table 3 reports descriptive statistics for size and for the variables included in the study, for the whole sample and per category (perennial and non-perennial group) as well.

Table 3. Descriptive statistics

\begin{tabular}{lllll}
\hline & \multicolumn{2}{l}{ Total sample } & Non-Perennial & Perennial \\
& Mean & Std. Dev. & Mean & Mean \\
\hline Financial distress & 0.5 & 0.5 & 1 & 0 \\
Total Assets* & 4973.15 & 35387.85 & 4862.35 & 5087.65 \\
Profitability & -0.37 & 1.46 & -0.7 & -0.06 \\
Liquidity & 2.24 & 3.32 & 1.25 & 3.12 \\
Solvency & 0.18 & 0.95 & -0.12 & 0.46 \\
\hline
\end{tabular}

* : In thousands USD.

First, let us notice that the pairing procedure regarding the total assets looks sound. Indeed, the difference in size between the two sub-samples is below 5 percent. Regarding our key explanatory variables, it appears that the profitability is higher for firms that have not known financial problems leading to a bankruptcy filing than for their counterparts. On average, the liquidity ratio is much higher for the perennial group of firms. Last, the solvency ratio is considerably different for the two subsamples. As expected, firms that did not resort to bankruptcy protection are clearly in a better position to face their financial obligations. In contrast, firms from the non-prerennial group report a negative solvency ratio, meaning that their equity is negative.

\subsection{Logit Regressions}

In this section, we briefly present the results of the logit model; the findings will be discussed in greater detail in the next section. The results of the logistic regression is shown in Table 4. 
Table 4. Logistic regression (dependent variable: financial distress)

\begin{tabular}{lll}
\hline Variable & Beta & Std. Err. \\
\hline Constant & $0.78^{* *}$ & 0.16 \\
Key variables & & \\
Profitability & $-1.76^{* * *}$ & 0.3 \\
Liquidity & $-0.13^{*}$ & 0.07 \\
Solvency & $-3.47^{* * *}$ & 0.4 \\
Model Chi2 & $343.33^{* * *}(3 \mathrm{df})$ & \\
Log Likelyhood & -350.29 & \\
Prediction accuracy & $83.82 \%$ & \\
\hline
\end{tabular}

Note: $\uparrow$ Partially significant at $\mathrm{P}<0.10 ;,{ }^{*}, * * * *$ Significant at $\mathrm{P}<0.05,0.01$, and 0.001 , respectively.

First, regarding the quality of the model, the Chi-Square value is significant at $1 \%$ threshold reflecting a very good model specification. Second, regarding direct effects, H1, which suggested that profitability had a negative impact on financial distress probability, is supported $(b=-1.76, p<.001)$. H2 posited a negative relationship between liquidity and the probability to file for a bankruptcy law; $\mathrm{H} 2$ supported at $5 \%$ threshold. $\mathrm{H} 3$, which suggested that solvency had a negative impact on financial distress probability, is also supported $(b=-3.47, p$ $<.001)$. Higher solvency ratio has a negative impact on the probability of filing for a bankruptcy chapter. Third, the prediction accuracy of the model is $83.82 \%$. This means that the model correctly classifies more than 80 percent of the firms into one on the two categories.

The findings are discussed in greater detail in the next section.

\section{Discussion and Conclusions}

The prediction of bankruptcy, also known as the prediction of financial distress, is a subject that is of interest for many actors. Lenders, investors or managers indeed aim to avoid bankruptcy. Inspired by existing models, we developed a logistic model to predict the bankruptcy of US firms over a period from 2000 to 2012. First, a literature review allowed us to formulate three working hypotheses regarding profitability, liquidity and solvency of the company. With reference to the literature, we selected the following three simple, uncorellated and easily accessible ratios: "net income / total assets", current ratio and "equity / total assets". Second, we built a paired sample including companies that went bankrupt and healthy firms. Aiming to predict bankruptcy, we then analyzed these data based on descriptive statistics and logistic model. Descriptive statistics report that healthy companies show better profitability, liquidity and solvency ratios. The econometric approach is performed using the STATA software to build the logit model applied to the U.S. case. Our results show that all our working hypotheses are supported; this results in a simple and accurate bankruptcy prediction model showing a prediction accuracy of $83.82 \%$.

There are limitations to this study. Firstly, our analysis is US centric; new models covering a different geographical area could be built to determine if the results are generalizable. Secondly, other methods, including those referring to artificial intelligence, could be tested in order to compare the results with those from logistic regressions. Finally, although the prediction models are used to understand bankruptcy, they do not guarantee a flawless dichotomy. Often, an additional analysis on a case by case situation seems necessary to foresee the risk of failure. There are theoretical and managerial implications of this research. This study contributes to the literature as it has been led on a long and recent timeframe. For shareholders and managers, this study reports that the use of three simple ratios may help to determine the probability of financial distress occurrence. Our study may help shareholders realise their investment choices. Financial institutions are obviously concerned by the risk of failure because their incomes directly depend on this.

\section{References}

Akers, M., Bellovary, J., \& Giacomino, D. (2007). A review of bankruptcy prediction studies: 1930 to present. Journal of Financial Education, 33(5), 1-42.

Altman, E. (1968). Financial ratios, discriminant analysis \& the prediction of corporate bankruptcy. The Journal of Finance, 23(4), 589-609. http://dx.doi.org/10.1111/j.1540-6261.1968.tb00843.x

Altman, E. (1999). Bankruptcy, \& distressed restructurings: Analytical issues, \& investment opportunities. Washington, DC: Beard Books.

Aziz, A., Emmanuel, D., \& Lawson, G. (1988). Bankruptcy prediction: An investigation of cash flow based 
$\begin{array}{lllll}\text { models. } & \text { Journal } & \text { of } & \text { Management }\end{array}$ http://dx.doi.org/10.1111/j.1467-6486.1988.tb00708.x

Bardos, M. (1989). Trois méthodes d'analyse discriminante. Cahiers Économiques, \& Monétaires de la Banque de France, 33(2), 151-189.

Bardos, M., \& Zhu, W. H. (1997). Comparaison de l'analyse discriminante linéaire, \& des réseaux de neurones: application à la détection de défaillance d'entreprises. Revue Statistique Appliquée, 45(4), 65-92.

Beaver, W. (1967). Financial ratios as predictors of failures. Journal of Accounting Research, 71-111.

Bell, G. G., Mossman, C. E., Swartz, L. M., \& Turtle, H. (1998). An empirical comparison of bankruptcy models. Financial Review, 33(2), 35-54. http://dx.doi.org/10.1111/j.1540-6288.1998.tb01367.x

Bilderbeek, J., \& Pompe, P. M. (2005). The prediction of bankruptcy of small and medium sized industrials firms. Journal of Business Venturing, 20(6), 847-868. http://dx.doi.org/10.1016/j.jbusvent.2004.07.003

Burgstahler, D., Jiambalvo, J., \& Noreen, E. (1989). Changes in the probability of bankruptcy, \& equity value. Journal of Accounting, \& Economics, 11, 207-224. http://dx.doi.org/10.1016/0165-4101(89)90006-2

Chang, N., Lee, G., \& Sung, T. K. (1999). Dynamics of modeling in data mining: Interpretative approach to bankruptcy prediction. Journal of Management Information System, 16(1), 63-85.

Daubie, M., \& Meskens, N. (2001). Bankruptcy prediction: Literature survey of the last ten years. Belgian Journal of Operational Research, Statistics and Computer Science, 41(1-2), 43-58.

Dimitras, A. I., Slowinski, R., Susmaga, R., \& Zapounidis, C. (1999). Business failure prediction using rough sets. European Journal of Operational Research, 114(2), 263-280. http://dx.doi.org/10.1016/S0377-2217(98)00255-0

Duffie, D., Saita, L., \& Wang, K. (2007). Multi-period corporate default prediction with stochastic covariates. Journal of Financial Economics, 83(3), 635-665. http://dx.doi.org/10.1016/j.jfineco.2005.10.011

Edminster, R. O. (1972). An empirical test of financial ratio analysis for small business failure prediction. Journal of Financial and Quantitative Analysis, 7(2), 1477-1493. http://dx.doi.org/10.2307/2329929

Flagg, J. C., Giroux, G. A., \& Wiggins, C. E. (1991). Predicting corporate bankruptcy using failing firms. Review of Financial Studies, 1(1), 67-78.

Gentry, J. A., Newblod, P., \& Whiteford, D. T. (1985). Classifying bankrupt firms with funds flow components. Journal of Accounting Research, 23(1), 146-160. http://dx.doi.org/10.2307/2490911

Keasey, K., \& McGuinness, P. (1990). The failure of UK industrials firms for the period 1976-1984, logistic analysis and entropy measures. Journal of Business Finance and Accounting, 17(1), 119-135. http://dx.doi.org/10.1111/j.1468-5957.1990.tb00553.x

Kim, M. J., \& Kang, D. K. (2010). Ensemble with neural networks for bankruptcy prediction. Expert Systems with Applications, 37(4), 3373-3379. http://dx.doi.org/10.1016/j.eswa.2009.10.012

Lennox, C. (1999). Identifying failing companies: A revaluation of the logit, probit and da approaches. Journal of Economics and Business, 51, 347-364. http://dx.doi.org/10.1016/S0148-6195(99)00009-0

Mensah, Y. M. (1984). An examination of the stationarity of multivariate bankruptcy prediction models: A methodological study. Journal of Accounting Research, 22(1), 380-395. http://dx.doi.org/10.2307/2490719

Odom, M., \& Sharda, R. (1990). A neural network model for bankruptcy prediction. Proceedings of the IEEE International Conference on Neural Network, 2, 163-168.

Ohlson, J. (1980). Financial ratios, \& the probabilistic prediction of bankruptcy. Journal of Accounting Research, 18(1), 109-131. http://dx.doi.org/10.2307/2490395

Platt, H. D., \& Platt, M. B. (1991). A note on the use of industry-relative ratios in bankruptcy prediction. Journal of Banking, \& Finance, 15(6), 1183-1194. http://dx.doi.org/10.1016/0378-4266(91)90057-S

Premachandra, I. M., Bhabra, G. S., \& Sueyoshi, T. (2009). DEA as a tool for bankruptcy assessment: A comparative study with logistic regression technique. European Journal of Operational Research, 193(2), 412-424. http://dx.doi.org/10.1016/j.ejor.2007.11.036

Refait, C. (2004). La prévision de la faillite fondée sur l'analyse financière de l'entreprise: un état des lieux. Economie, \& Prévision, 162(1), 129-147.

Shin, K. S., \& Lee, Y. J. (2002). A genetic algorithm application in bankruptcy prediction modeling. System 
Experts with Applications, 23(3), 637-646. http://dx.doi.org/10.1016/S0957-4174(02)00051-9

Shumway, T. (2001). Forecasting bankruptcy more accurately: A simple hazard model. Journal of Business, 74(1), 101-124. http://dx.doi.org/10.1086/209665

Varetto, F. (1998). Genetic algorithms applications in the analysis of insolvency risk. Journal of Banking and Finance, 22(10-11), 1421-39. http://dx.doi.org/10.1016/S0378-4266(98)00059-4

Zavgren, C. (1985). Assessing the vulnerability of failure of American industrial firms: a logistic analysis. $\begin{array}{lllll}\text { Journal of Business Finance, \& } \quad \text { Accounting, } & 12(1), & 19-45 .\end{array}$ http://dx.doi.org/10.1111/j.1468-5957.1985.tb00077.x

Zmijewski, M. (1984). Methodological issues related to the estimation of financial distress prediction models. Journal of Accounting Research, 22, 59-82. http://dx.doi.org/10.2307/2490859

\section{Note}

Note 1. http://www.uscourts.gov/bankruptcycourts/bankruptcybasics/process.html

\section{Copyrights}

Copyright for this article is retained by the author(s), with first publication rights granted to the journal.

This is an open-access article distributed under the terms and conditions of the Creative Commons Attribution license (http://creativecommons.org/licenses/by/3.0/). 